facts that the creation of a Minister for Science and the existence of an Advisory Council for Scientific Policy in Britain, together with the clear recognition that Britain's contribution to space research should be made on an international basis, place this country in an advantageous position to co-operate in this way, is no ground for complacency. The suggestions made in this report and their implications deserve to be closely considered by the Minister for Science, the Advisory Council for Scientific Policy and the Overseas Research Council at least, with a view both of increasing our present effort and ensuring that it is concerted as effectively as possible in co-operation with that of other nations.

\section{POST-MORTEM ON GROUNDNUTS?}

Agriculture and Ecology in Africa

A Study of Actual and Potential Development South of the Sahara. By Prof. John Phillips. Pp. 424. (London: Faber and Faber, Ltd., 1959.) 63s. net.

DOLITICAL advances in tropical Africa can only be successful if economic progress is accelerated. Industrial developments are important, but for many years agriculture in one form or another will be the major industry of all the countries in Africa south of the Sahara. Today agricultural progress is slow, and where crops have brought prosperity, as cocoa has to Ghana, this is because the price has risen disproportionately to the rise in other world prices, and not because the yield has risen substantially. Unless methods of agriculture in many countries are greatly improved, as the population increases even the present pitifully low standards of living will be difficult to maintain.

Prof. Phillips's book is about this problem. He has been himself concerned with ecological and agricultural works in many parts of Africa for nearly forty years. $\mathrm{He}$ was the botanical ecologist in Swynnerton's team of tsetse fly investigators in Tanganyika. He was professor of botany at the University of the Witwatersrand. He was one of the senior scientists concerned with the ill-fated East African groundnut scheme. Since 1952 he has been professor of agriculture in the University College in Ghana. Few men can have seen so much of African agriculture, and have been made so aware of its problems.

In this book an immense amount of information about the climate, soil, crops and people of Africa is brought together. It must have been a tremendous task for the author to make this compilation, and his book will at least serve as an invaluable work of reference to those unable to go to the original sources. I do not think that it will succeed so well in its avowed purpose "to awaken those concerned with Africa to the necessity of adjusting both traditional and modern agriculture to the ecological, sociological and psychological settings of the Trans-Sahara".

The first disadvantage of this volume is that it is so difficult to read. The (very valuable) data are set out at length, usually undigested, and I found I could only assimilate those in which I had some particular and personal interest. Between the data the reader is treated to infuriating examples of flowery prose in Prof. Phillips's own particular style. In one paragraph three consecutive sentences start:
"Sketchy is the information ...": "Essential is the need ...". "Unnecessary is a review ...". We are, however, left with a true picture of Africa, vast, varied, and (in the main) unproductive; but this could have been much more easily achieved and with less strain on the reader.

What should have been the most valuable chapter compares three large-scale development schemes. These are the Sudan Gezira Scheme, the East African Groundnut Scheme, and the proposed Volta River Project in Ghana. We are shown how fundamentally different the conditions for the successful Gezira Scheme and the groundnut fiasco were, but instead of a straightforward account of each we are treated to a point-by-point comparison of features which are not always strictly comparable. We can in the end only conclude that in the Gezira conditions were favourable, and in Tanganyika everything was done in too great a hurry.

It is difficult to imagine how this book can have any important and practical results. We are told that agriculture must be ecological, which simply means that we must learn to grow the correct crops by the best methods in the best places. We are not told how to do this, except that we must not be in too much of a hurry, and that research must be properly coordinated.

In my opinion the trouble with African agriculture is not that information is not properly co-ordinated, but that the basic facts are simply not known. So little fundamental agricultural research has been done. Even in Britain we spend more in subsidizing our poultry industry for a month than we spend on agricultural research in a year; in Africa, with its immense areas and problems, we spend much less. Even attempts at developments like the Groundnut Scheme, into which millions of pounds were poured, seem less wasteful when it is realized that for every pound lost in this and in all agricultural schemes attempted in Africa since the War, much more than a hundred pounds has been spent in subsidizing British agriculture at home. More money will have to be spent on research in Africa. We need to have more and better research workers in the laboratories and in the field; I believe they will use the limited resources better than those who fritter away so much time and money attending international conferences and endless meetings of co-ordinating committees which lack the basic facts to co-ordinate. If the newly independent territories in Africa can learn this lesson, and develop an environment favourable to working scientists (expatriate as well as local), there is a reasonable chance that they may learn to take proper advantage of the ecological conditions of their countries in agriculture as in other fields of development.

KenNeTh MeLLANBY

\section{CHANGING COASTLINES}

\section{Beaches and Coasts}

By Dr. C. A. M. King. Pp. xii +403 . (London : Edward Arnold (Publishers), Ltd., 1959.) 65s. net. $T^{T}$ is now forty years since the publication of $\mathrm{D}$. W. Johnson's pioneer and now classic work "Shore Processes and Shoreline Development". In the meantime much work has been carried out, both theoretical and practical, on the processes at work along the coasts and the evolution of different types of shoreline. Problems of coast erosion and, equally, of coastal 